2015

\title{
What Are You Reading? An Analysis of 100,000 Numeracy Article Downloads
}

Nathan D. Grawe

Carleton College

Follow this and additional works at: https://digitalcommons.usf.edu/numeracy

Part of the Education Commons

\section{Recommended Citation}

Grawe, Nathan D.. "What Are You Reading? An Analysis of 100,000 Numeracy Article Downloads." Numeracy 8, Iss. 2 (2015): Article 1. DOI: http://dx.doi.org/10.5038/1936-4660.8.2.1 


\title{
What Are You Reading? An Analysis of 100,000 Numeracy Article Downloads
}

\author{
Abstract \\ This editorial celebrates the first 100,000 downloads of items published in Numeracy. An analysis of item \\ titles suggests readers prefer titles referencing "numeracy" over "quantitative literacy" and those dealing \\ with mathematics and finance. As we look toward the next 100,000 downloads we aspire to greater \\ diversity in readership that diminishes disciplinary differences. \\ Keywords \\ Numeracy downloads \\ Creative Commons License \\ (c) (i) (9)
}

This work is licensed under a Creative Commons Attribution-Noncommercial 4.0 License

\section{Cover Page Footnote}

Nathan D. Grawe is Professor and Chair of Economics at Carleton College. His involvement in quantitative reasoning has focused on assessment and faculty development. He is co-editor of this journal. 
On May 11 of this year Numeracy recorded its 100,000 ${ }^{\text {th }}$ article download (Fig 1). ${ }^{1} \quad$ It is worth pausing for a moment to reflect with satisfaction on the implications of so many downloads for the 136 items published over a little less than 7.5 years. While the number of close readings undoubtedly falls short of the download figure, one thing remains clear: Numeracy has succeeded in creating a place for professional discourse around the advancement of quantitative reasoning. ${ }^{2}$

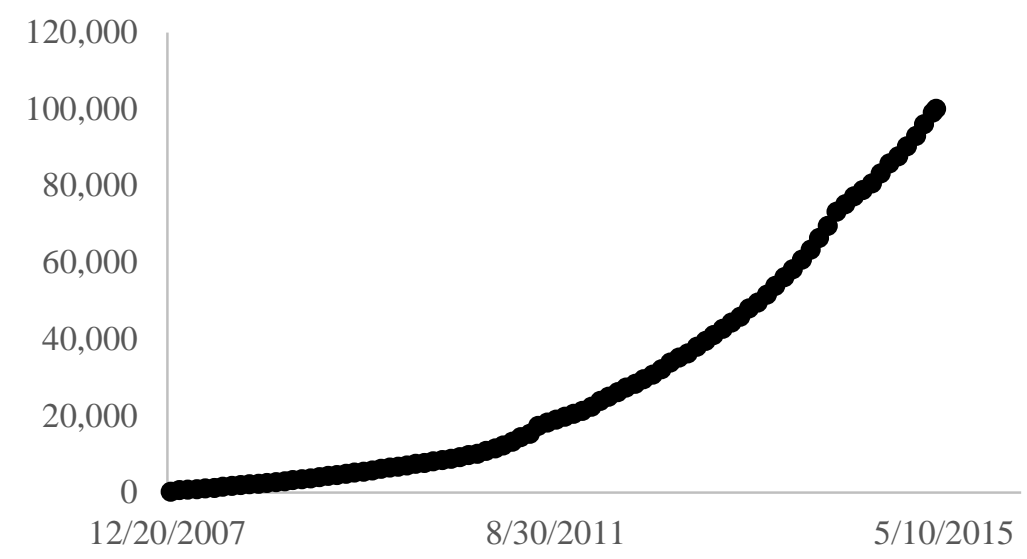

Figure 1. Total Numeracy article downloads December 20, 2007 through May 11, 2015

With a large sample of papers and downloads, we can explore what types of papers draw readers' attention. Through an examination of titles, I coded all Numeracy items along two dimensions. In light of Vacher's (2014) discussion of definitional distinctions between "numeracy," "quantitative literacy," and "quantitative reasoning” I code each title for uses of these terms (and slight variations). Second, I note explicit references to recurring topic areas: assessment, teaching, mathematics or specific mathematics courses/subjects, medicine, and finance. I control for the type of paper (article, perspective, review, note, editorial, column) to account for differences by genre. Because papers appearing in earlier volumes have had more time to be downloaded, I also control for the natural log of days since publication. Table 1 reports summary statistics for all variables in my model.

\footnotetext{
${ }^{1}$ Some readers may recall an editorial marking the $5,000^{\text {th }}$ Numeracy downloads in October of 2009, less than two years after the journal's inaugural publication (Vacher 2010). Using quadratic and power-function growth models Vacher predicted we would reach 10,000 downloads on March 2, 2011 or October 3, 2010, respectively. In fact, we reached that mark at the very end of 2010.

${ }^{2}$ The wide variation in download numbers across papers and the correlation in downloads of individual papers across time suggest a human reader rather than spambots randomly navigating internet sites.
} 
Table 1

Sample summary statistics

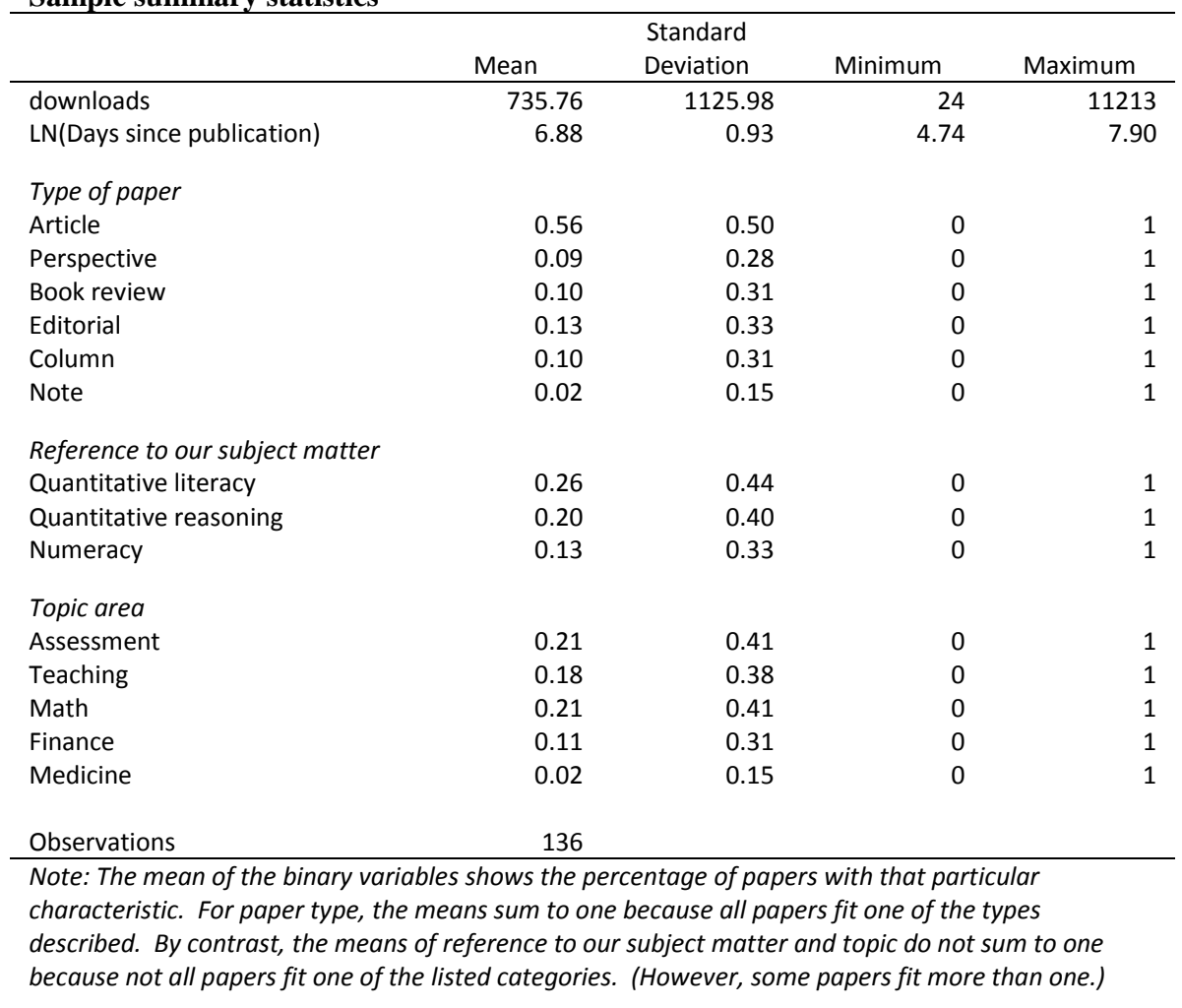

Table 2 presents regression results for three samples. Because every paper falls into one of the types, I exclude a dummy variable for articles to avoid perfect multicollinearity; the other type coefficients should be interpreted as number of reads relative to an article. The first (column 1) includes all items published in Numeracy through May 11 when we crossed the 100,000 download milestone. Outside the control variables, the only predictor of statistical significance is the topic area medicine. However, the extraordinarily large coefficient suggests we should be skeptical of the result. Only three paper titles refer to medicine and one of these papers (Price and Ansari 2013) is a clear outlier, drawing more than 11,000 downloads.

Column 2 repeats the analysis excluding this outlier. Based on column 2, Numeracy readers may prefer titles which include "numeracy" rather than "quantitative literacy” (a mean difference of 322.60 downloads with a standard error of 194.46). The download advantage for titles explicitly mentioning mathematics and finance is even stronger. Because columns and editorials are not peer reviewed and because the statistical analysis suggests readers respond differently to these pieces, I repeated the regression on a sample which excludes the 30 observations of this type (column 3). Exclusion of such pieces makes no 
meaningful difference to the model coefficients; all coefficients and $p$-values are substantially unaltered except that readers' preference for "numeracy" over “quantitative literacy” is slightly clearer.

Table 2

Regression coefficients of Numeracy downloads on paper characteristics

\begin{tabular}{|c|c|c|c|}
\hline & Model 1 & Model 2 & Model 3 \\
\hline LN(Days since publication) & $\begin{array}{l}293.52 \\
(99.13)\end{array}$ & $\begin{array}{l}282.50 \\
(61.26)\end{array}$ & $\begin{array}{l}336.35 \\
(77.47)\end{array}$ \\
\hline \multicolumn{4}{|l|}{ Type of paper } \\
\hline Perspective & $\begin{array}{r}-131.23 \\
(324.80)\end{array}$ & $\begin{array}{r}-194.37 \\
(200.76)\end{array}$ & $\begin{array}{r}-238.84 \\
(226.51)\end{array}$ \\
\hline Book review & $\begin{array}{r}-281.58 \\
(302.25)\end{array}$ & $\begin{array}{r}-117.21 \\
(187.14)\end{array}$ & $\begin{array}{r}-145.37 \\
(210.84)\end{array}$ \\
\hline Editorial & $\begin{array}{r}-393.09 \\
(280.45)\end{array}$ & $\begin{array}{r}-371.96 \\
(173.31)\end{array}$ & \\
\hline Column & $\begin{array}{r}-754.88 \\
(322.60)\end{array}$ & $\begin{array}{r}-446.70 \\
(200.56)\end{array}$ & \\
\hline Note & $\begin{array}{r}-388.08 \\
(619.34)\end{array}$ & $\begin{array}{r}-435.93 \\
(382.73)\end{array}$ & $\begin{array}{r}-501.75 \\
(432.36)\end{array}$ \\
\hline Reference to our subject mo & & & \\
\hline Quantitative literacy & $\begin{array}{r}-449.54 \\
(210.03)\end{array}$ & $\begin{array}{r}-60.35 \\
(132.72)\end{array}$ & $\begin{array}{r}-163.11 \\
(166.73)\end{array}$ \\
\hline Quantitative reasoning & $\begin{array}{r}-56.71 \\
(239.76)\end{array}$ & $\begin{array}{r}97.92 \\
(148.57)\end{array}$ & $\begin{array}{r}9.96 \\
(197.16)\end{array}$ \\
\hline Numeracy & $\begin{array}{r}-209.68 \\
(280.76)\end{array}$ & $\begin{array}{r}262.26 \\
(176.72)\end{array}$ & $\begin{array}{r}273.79 \\
(231.14)\end{array}$ \\
\hline Topic area & & & \\
\hline Assessment & $\begin{array}{r}-108.92 \\
(241.60)\end{array}$ & $\begin{array}{r}120.69 \\
(150.19)\end{array}$ & $\begin{array}{r}146.09 \\
(176.65)\end{array}$ \\
\hline Teaching & $\begin{array}{r}-202.20 \\
(241.87)\end{array}$ & $\begin{array}{r}-198.69 \\
(149.46)\end{array}$ & $\begin{array}{r}-209.51 \\
(175.41)\end{array}$ \\
\hline Math & $\begin{array}{r}168.84 \\
(249.48)\end{array}$ & $\begin{array}{r}501.67 \\
(155.98)\end{array}$ & $\begin{array}{r}556.69 \\
(190.58)\end{array}$ \\
\hline Finance & $\begin{array}{r}186.91 \\
(301.19)\end{array}$ & $\begin{array}{r}411.40 \\
(186.80)\end{array}$ & $\begin{array}{r}395.82 \\
(223.34)\end{array}$ \\
\hline Medicine & $\begin{array}{r}3644.53 \\
592.33)\end{array}$ & $\begin{array}{r}-208.54 \\
(457.58)\end{array}$ & $\begin{array}{r}-158.96 \\
(518.61)\end{array}$ \\
\hline Constant & $\begin{array}{r}-1033.27 \\
(745.79)\end{array}$ & $\begin{array}{r}-1327.82 \\
(461.34)\end{array}$ & $\begin{array}{r}-1656.92 \\
(575.28)\end{array}$ \\
\hline
\end{tabular}

Observations

136

135 104

Notes: Standard errors in parentheses.

The preference for titles referring to "numeracy" rather than "quantitative literacy" seems to confirm Vacher's (2014) contention that while many use these terms interchangeably, nuanced distinctions of importance remain. If "literacy" suggests mastery of very basic skills, perhaps the download patterns provide evidence that the Numeracy audience has stronger interest in discussions of higher order thinking skills. On the other hand, in some circles "numeracy" refers to acquisition of the earliest math skills, so the interpretation of this result is very speculative. 
Higher download rates for titles mentioning mathematics suggests the National Numeracy Network may appeal disproportionately to those identifying with that discipline. The download advantages predicted for a mathematics title in models 2 and 3 are approximately 70 percent of the sample mean. That is hardly trivial. As Steen (2004) and others have argued, strong interdisciplinary engagement is essential for our movement's success. As an editorial staff we remain committed to publishing and promoting interdisciplinary approaches to numeracy and hope disciplinary differences in reading will diminish as readership diversifies in the next 100,000 downloads.

Finally, titles referencing finance hold a download advantage that rivals that of mathematics. (This result is essentially unchanged when excluding papers in the financial literacy theme collection published in issue 2 of volume 6.) Perhaps the popularity of the papers points to readers' interests in constructive and practical contributions to our teaching and thinking. (The download-leading paper by Price and Ansari 2013 also fits this description despite a very different subject matter.) In coming years I hope our scholarly community can identify more such nodes of scholarship to demonstrate the broad importance of numeracy well beyond the mathematics classroom.

\section{Acknowledgment}

I thank Len Vacher for helpful comments on an earlier version of this essay. All remaining errors are my own.

\section{References}

Price, G. R. and D. Ansari. 2013. Dyscalculia: Characteristics, Causes, and Treatments. Numeracy 6 (1): Article 2. http://dx.doi.org/10.5038/19364660.6.1.2

Steen, L. A. Achieving Quantitative Literacy: An Urgent Challenge for Higher Education. Washington, DC: Mathematical Association of America

Vacher, L. 2010. Five thousand downloads. Numeracy 3 (1): Article 1. http://dx.doi.org/10.5038/1936-4660.3.1.1

Vacher, L. 2014. Looking at Multiple Meanings of Numeracy, Quantitative Literacy, and Quantitative Reasoning. Numeracy 7 (2): Article 1. http://dx.doi.org/10.5038/1936-4660.7.2.1 